Edunomika - Vol. 02, No. 01 (Pebruari 2018)

\title{
PENINGKATAN HASIL BELAJAR MENDISKRIPSISKAN TEKS SEDERHANA BENTUK UNDANGAN DAN BAGIAN-BAGIANNYA MELALUI MODEL PEMBELAJARAN CONTEKSTUAL (CTL) PADA SISWA KELAS 8 G SEMESTER 1 SMP NEGERI 6 SUKOHARJO TAHUN PELAJARAN 2017/2018
}

\author{
Erna Rumiyatun \\ SMP Negeri 6 Sukoharjo, Jawa Tengah \\ Email: ernarumiyatun@gmail.com
}

\begin{abstract}
Abstrak: Penelitian ini bertujuan untuk meningkatkan hasil belajar bahasa Inggris materi mendiskripsiskan teks sederhana bentuk undangan dan bagian-bagiannya pada siswa kelas 8 G SMP Negeri 6 Sukoharjo semester I Tahun Pelajaran 2017/2018 melalui penerapan pendekatan kontekstual. Penelitian ini menggunakan bentuk penelitian tindakan kelas yang dilaksanakan dalam 2 (dua) siklus, dilaksanakan di SMP Negeri 6 Sukoharjo dengan subjek penelitian seluruh siswa kelas 8 G SMP Negeri 6 Sukoharjo yang berjumlah 20 siswa. Metode penelitian menggunakan Penelitian Tindakan Kelas. Pengumpulan data dilakukan melalui observasi, dokumentasi dan tes. Analisis data dilakukan dengan 3 (tiga) tahapan meliputi: reduksi data, penyajian data dan penarikan kesimpulan atau verifikasi. Hipotesis menyatakan diduga melalui penerapan pendekatan kontekstual dapat meningkatkan hasil belajar bahasa Inggris materi mendiskripsiskan teks sederhana bentuk undangan dan bagian-bagiannya pada siswa kelas 8 G SMP Negeri 6 Sukoharjo semester I Tahun Pelajaran 2017/2018. Dari data empirik menyatakan melalui penerapan pendekatan kontekstual dapat meningkatkan hasil belajar bahasa Inggris materi mendiskripsiskan teks sederhana bentuk undangan dan bagian-bagiannya dari kondisi awal nilai rata-rata 70 dengan ketuntasan 55\% ke kondisi akhir pada siklus II nilai rata-rata 80 dengan ketuntasan 85\% pada siswa kelas 8 G SMP Negeri 6 Sukoharjo semester I Tahun Pelajaran 2017/2018. Sehingga dapat disimpulkan bahwa melalui penerapan pendekatan kontekstual dapat meningkatkan hasil belajar bahasa Inggris materi mendiskripsiskan teks sederhana bentuk undangan dan bagian-bagiannya pada siswa kelas 8 G SMP Negeri 6 Sukoharjo semester I Tahun Pelajaran 2017/2018.
\end{abstract}

Kata Kunci: hasil belajar, bahasa Inggris, mendiskripsiskan teks sederhana bentuk undangan dan bagian-bagiannya, pendekatan kontekstual

Abstract: This study aims to improve the learning outcomes of English material
mendiscripsiskan simple text form of invitation and its parts on 8 th grade students of SMP
Negeri 6 Sukoharjo first semester of Lesson $2017 / 2018$ through the application of
contextual approach. This study uses a classroom action research conducted in 2 (two)
cycles, implemented in SMP Negeri 6 Sukoharjo with the subject of research all students of
grade 8 G SMP Negeri 6 Sukoharjo which amounted to 20 students. Research method
using Classroom Action Research. Data collection is done through observation,
documentation and test. Data analysis was done with 3 (three) stages including: data
reduction, data presentation and conclusion or verification. Hypothesis states allegedly
through the application of contextual approach can improve learning outcomes English 
material mendiscripsiskan simple text form of invitation and its parts on the student grade 8 G SMP Negeri 6 Sukoharjo first semester Lesson 2017/2018. From the empirical data states through the application of contextual approach can improve the English learning result of the material to describe the simple text of invitation form and its parts from the initial condition of the average value of 70 with the completeness $55 \%$ to the final condition in cycle II the average value 80 with the completeness $85 \%$ in grade 8 students of SMP Negeri 6 Sukoharjo in the first semester of Study Year 2017/2018. So it can be concluded that through the application of contextual approach can improve learning outcomes English material mendiskripsiskan simple text form of invitation and its parts on the students of grade 8 G SMP Negeri 6 Sukoharjo first semester Lesson 2017/2018.

Keywords: learning outcomes, English, describe simple text of invitation form and its parts, contextual approach

\section{PENDAHULUAN}

Bahasa Inggris adalah bahasa internasional dalam menyongsong globalisasi. Oleh karena itu, bahasa Inggris sudah menjadi mata pelajaran wajib yang diselenggaran dari sekolah dasar bahkan sampai perguruan tinggi tentunya melalui kegiatan belajar mengajar. Kegiatan belajar akan lebih efektif jika melalui pendidikan formal. Dimana Pendidikan menjadi motor penggerak bagi keberlangsungan sumber daya manusia yang handal suatu negara, karena pendidikan merupakan cara terbaik untuk meningkatkan kualitas sumber daya manusia suatu bangsa (Tho'in, 2017: 162). Sehingga pendidikan menjadi suatu aspek kehidupan yang sangat mendasar bagi pembangunan bangsa. Penyelenggaraan pendidikan di sekolah melibatkan guru sebagai pendidik dan siswa sebagai peserta didik.

Kegiatan belajar mengajar yang disampaikan kepada siswa, khususnya siswa setingkat sekolah menengah pertama (SMP), perlu dilakukan dengan arif dan bijaksana agar mata pelajaran yang akan kita sampaikan benar-benar dapat diterima oleh siswa didik kita dengan baik dan benar. Tentunya masing-masing mata pelajaran harus disampaikan dengan metode atau pendekatan yang sesuai dengan ciri khas mata pelajaran itu sendiri. Ketepatan atau tidaknya metode atau pendekatan yang dilakukan guru dalam menyampaikan mata pelajaran yang diampunya sangat menentukan tingkat prestasi belajar yang diperoleh dari siswa-siswa didiknya tersebut. Jika tepat tentunya prestasinya akan semakin baik, namun sebaliknya jika tidak tepat prestasi belajar siswa justru bisa turun.

Mata pelajaran bahasa Inggris ini cukup sulit dipahami jika tidak disampaikan dengan metode yang benar, kesulitan itu karena terkadang muncul pula pada diri guru sendiri yang merasa malu atau bahkan canggung jika ingin menyampaikan kepada anak-anak remaja setingkat SMP terkait masalah mendiskripsiskan teks sederhana bentuk undangan dan bagian-bagiannya. Dengan demikian bukan hanya siswa saja yang merasa terbebani tetapi gurupun juga merasa janggung. Oleh sebab itu, diperlukan suatu konsep atau metode yang tepat agar anak dapat menangkap materi ini secara baik dan benar.

Pada mata pelajaran bahasa Inggris sebagian besar materinya berisi deskriptif, biasanya metode yang digunakan oleh guru adalah metode ceramah. Guru dalam melaksanakan pembelajaran bahasa Ingrris ini menularkan pengetahuan dan informasi dengan menggunakan 
lisan. Dari hal ini dapat dilihat bahwa keaktifan siswa kurang berperan, sehingga untuk berfikir kreatifpun siswa mengalami hambatan, selain itu metode ceramah ini menimbulkan rasa bosan pada siswa, sehingga metode ini dirasa kurang efektif. Oleh karena itu, dalam proses belajarmengajar perlu adanya pendekatan pembelajaran yang lebih efektif dan mampu menciptakan suasana yang dapat mengaktifkan siswa khususnya pada mata pelajaran bahasa Inggris materi mendiskripsiskan teks sederhana bentuk undangan dan bagian-bagiannya kelas $8 \mathrm{G}$ semester I SMP Negeri 6 Sukoharjo tahun pelajaran 2017/2018.

Berdasarkan hasil pembelajaran awal yang saya lakukan kepada siswa kelas $8 \mathrm{G}$ SMP Negeri 6 Sukoharjo bahwa ada masalah dalam pembelajaran materi mendiskripsiskan teks sederhana bentuk undangan dan bagian-bagiannya dimana siswa cenderung pasif saat pembelajaran berlangsung. Para siswa mengalami kesulitan dalam memahami materi tersebut. Kriteria kelulusan minimal (KKM) untuk mata pelajaran bahasa Inggris materi mendiskripsiskan teks sederhana bentuk undangan dan bagian-bagiannya juga lebih rendah dibandingkan dengan mata pelajaran lain. Sebagian besar siswa kelas $8 \mathrm{G}$ juga belum memenuhi KKM dalam materi mendiskripsiskan teks sederhana bentuk undangan dan bagian-bagiannya.

Burhan Nurgiyantoro (2012: 487) menjelaskan bahwa untuk membangkitkan minat siswa dan merangsang imajinasi peserta didik dapat dibawa keluar kelas atau memanfaatkan saat pergi seperti darmawisata atau rekreasi. Pembelajaran keluar kelas tersebut ada dalam pembelajaran yang berbasis pendekatan kontekstual sehingga penggunakan pendekatan ini diharapkan lebih mempermudah, memperlancar dan membantu dalam penyampaian materi serta mempengaruhi hasil belajar siswa karena dalam proses pembelajaran kontekstual (1) keterampilan dikembangkan atas dasar pemahaman; (2) pembelajaran terjadi di berbagai tempat, konteks, dan setting; (3) pembelajaran dikaitkan dengan kehidupan nyata dan atau masalah yang disimulasikan; dan (4) bahasa yang diajarkan dengan pendekatan komunikatif, yakni siswa diajak menggunakan bahasa dalam konteks nyata (Ditjen Dikdasmen, 2003: 7-9).

Pembelajaran Kontekstual (Contextual Teaching and Learning/CTL) merupakan pendekatan pembelajaran yang mengaitkan antara materi yang dipelajari dengan kehidupan nyata siswa sehari-hari, baik lingkungan keluarga, sekolah, masyarakat, maupun warga negara, dengan tujuan menemukan makna materi tersebut bagi kehidupannya (Kokom Komalasari, 2013: 7). Dengan penerapan konsep tersebut dalam pembelajaran materi mendiskripsiskan teks sederhana bentuk undangan dan bagian-bagiannya diharapkan hasilnya akan lebih bermakna bagi siswa. Proses pembelajaran berlangsung lebih alamiah dalam bentuk kegiatan siswa bekerja dan mengalami, bukan transfer pengetahuan dari guru ke siswa. dengan melibatkan tujuh komponen utama pembelajaran efektif, yakni: konstruktivisme (constructivism), bertanya (questioning), menemukan (inquiri), masyarakat belajar (learning community), pemodelan (modeling), dan penilaian sebenarnya (authentic assessment). 


\section{KAJIAN TEORI}

\section{Teori Hasil Belajar Siswa}

Menurut R. Gagne seperti yang dikutip oleh Slameto (2000:78) memberikan dua definisi belajar, yaitu belajar adalah suatu proses untuk memperoleh motivasi dalam pengetahuan, keterampilan, kebiasaan, dan tingkah laku. Belajar adalah penguasaan pengetahuan atau keterampilan yang diperoleh dari instruksi. Menurut Skinner yang dikutip oleh Dimyati dan Mudjiono (2006:93) bahwa belajar merupakan hubungan antara stimulus dan respon yang tercipta melalui proses tingkah laku. M. Sobry Sutikno (2010:35) mengemukakan belajar merupakan suatu proses usaha yang dilakukan oleh seseorang untuk memperoleh suatu perubahan yang baru sebagai hasil pengalamannya sendiri dalam interaksi dengan lingkungannya.

Berdasarkan beberapa pengertian di atas maka dapat penulis simpulkan bahwa belajar adalah perubahan serta peningkatan kualitas dan kuantitas tingkah laku seseorang di berbagai bidang yang terjadi akibat interaksi terus menerus dengan lingkungannya.

Hasil belajar siswa menurut W. Winkel (2004:82) adalah keberhasilan yang dicapai oleh siswa, yakni prestasi belajar siswa di sekolah yang mewujudkan dalam bentuk angka. Hasil belajar adalah pola-pola perbuatan, nilai-nilai, pengertian-pengertian, sikap-sikap, apresiasi dan keterampilan-keterampilan (Suprijono, 2011:5). Hasil belajar adalah hasil yang dicapai dalam bentuk angka atau skor setelah tes hasil belajar pada setiap akhir pembelajaran (Dimyati dan Mujiono, 2006:24).

Definisi di atas dapat disimpulkan bahwa hasil belajar adalah prestasi belajar yang dicapai siswa dalam proses kegiatan belajar mengajar dengan membawa suatu perubahan dan pembentukan tingkah laku seseorang. Untuk menyatakan bahwa suatu proses belajar dapat dikatakan berhasil, setiap guru memiliki pandangan masing-masing sejalan dengan filsafatnya. Namun untuk menyamakan persepsi sebaiknya kita berpedoman pada kurikulum yang berlaku saat ini yang telah disempurnakan, antara lain bahwa suatu proses belajar mengajar tentang suatu bahan pembelajaran dinyatakan berhasil apabila tujuan pembelajaran khususnya dapat dicapai.

Dalam rangka mengetahui tercapai tidaknya tujuan pembelajaran khusus, guru perlu mengadakan tes formatif pada setiap menyajikan suatu bahasan kepada siswa. Penilaian formatif ini untuk mengetahui sejauh mana siswa telah menguasai tujuan pembelajaran khusus yang ingin dicapai. Fungsi penelitian ini adalah untuk memberikan umpan balik pada guru dalam rangka memperbaiki proses belajar mengajar dan melaksanakan program remedial bagi siswa yang belum berhasil. Karena itulah, suatu proses belajar mengajar dinyatakan berhasil apabila hasilnya memenuhi tujuan pembelajaran khusus dari bahan tersebut.

Hasil belajar yang dicapai oleh siswa di sekolah merupakan salah satu ukuran terhadap penguasaan materi pelajaran yang disampaikan. Peran guru dalam menyampaikan materi pelajaran dapat mempengaruhi hasil belajar siswa. Faktor-faktor yang mempengaruhi hasil belajar siswa penting sekali untuk diketahui, artinya dalam rangka membantu siswa mencapai hasil belajar yang seoptimal mungkin. 
Hasil belajar yang dicapai siswa dipengaruhi oleh dua faktor baik yang bersifat mendorong atau menghambat, demikian pula dalam belajar. Faktor yang mempengaruhi prestasi atau hasil belajar siswa yakni faktor dari dalam diri siswa (interen) dan faktor yang datang dari luar (eksteren). Ahmadi (1998:72) mengemukakan untuk mencapai prestasi belajar siswa sebagaimana yang diharapkan, maka perlu diperhatikan beberapa faktor yang mempengaruhinya antara lain faktor yang terdapat dalam diri siswa (faktor intern) dan faktor yang berasal dari luar diri siswa (faktor ekstern).

\section{Mendiskripsikan Teks}

Definisi Teks Deskripsi adalah sebuah karangan yang gagasan utamanya disampaikan dengan cara menggambarkan secara jelas objek, tempat atau peristiwa yang sedang menjadi topik kepada pembaca, yang sehingga pembaca seolah-olah merasakan langsung apa yang sedang diungkapkan dalam teks tersebut.

Menurut Keraf (1995), Deskripsi juga bisa didefinisikan sebagai suatu wacana yang berusaha menyajikan suatu hal atau objek pembicaraan yang seakan-akan para pembaca melihat sendiri objek tersebut se olah-olah berada di depan mata para pembaca. Sedangkan menurut Tarigan (1994), deskrisi adalah Tulisan yang bisa melukiskan sebuah kisah dengan tujuan untuk mengajak pembaca memahami merasakan dan menikmati objek yang dibicarakan seperti suasana hati, orang aktivitas dan sebagainya. Untuk membedakan teks deskripsi dengan teks lainnya simaklah ciri-ciri teks deskripsi sebagai berikut: Paragraf/karangan deskripsi menggambarkan atau melukiskan sesuatu; Paragraf yang digambarkan dijelaskan secara sangat jelas dan rinci serta melibatkan kesan indera; Ketika pembaca membaca teks deskripsi, maka seolah-olah merasakan langsung apa yang sedang dibahas di dalam teks; Penggambaran atau penjelasan suatu objek yang menjadi topik di tuliskan secara detail; Teks deskripsi menjelaskan ciri-ciri fisik objek, seperti bentuk, ukuran, warna, atau ciri-ciri psikis/keadaan suatu objek dengan rinci.

Tesk deskripsi dibedakan menjadi dua jenis yakni teks deskripsi imaginatif dan teks deskripsi faktual. Pertama, Deskripsi Imajinatif (Impresionis). Deskripsi imajinatif atau impresionis adalah paragraf yang melukiskan ruang atau tempat berlangsungnya suatu peristiwa. Pelukisannya harus dilihat dari berbagai segi agar ruang tersebut tergambar dengan jelas dalam pikiran dan perasaan pembaca. Kedua, Deskripsi faktual/ekspositoris. Deskripsi faktual/ekspositoris adalah paragraf yang menggambarkan suatu hal atau orang dengan mengungkapkan identitasnya secara apa adanya sehingga pembaca dapat membayangkan keadaannya. Agar suatu objek mampu membangkitkan daya khayal pada diri pembaca, penulis harus melukiskannya dari berbagai sudut pandang. Semakin rinci penulisannya, semakin jelas tergambar dalam bayangan pembaca. Apabila objek yang dilukiskan itu adalah seseorang, perinciannya dapat dilakukan terhadap aspek fisik maupun aspek rohaninya. Aspek rohani meliputi perasaan, watak, bakat, peranannya dalam suatu bidang kerja, dan sebagainya.

\section{Undangan dan Bagian-bagiannya}

Undangan berasal dari kata dasar "undang" dan akhiran "an". Undang berarti panggil. Mengundang berarti memanggil atau mempersilakan datang. Undangan adalah 
kata benda yang berarti orang yang dipanggil atau dipersilakan datang untuk hadir pada waktu, hari, tanggal, tempat yang sudah ditetapkan dalam undangan. Surat undangan merupakan suatu penghormatan kepada orang yang diundang. Bentuk dan susunan surat undangan hendaknya disusun semenarik mungkin, jelas isinya dan dikirimkan tepat waktu agar yang diundang dapat mempersiapkan untuk memenuhi undangan tersebut.

Dengan demikian, surat undangan adalah surat pemberitahuan akan adanya suatu acara/kegiatan pertemuan, upacara dengan harapan agar penerima undangan dapat hadir pada waktu dan tempat yang telah ditetapkan.

Bagian-bagian Surat Undangan

a. Kepala Surat, yang terdiri dari: nama badan usaha, alamat badan usaha, nomor telepon, nomor kotak pos, identitas lainnya, tanggal surat, nomor yang ditujukan/alamat dalam.

b. Isi Surat, yang terdiri dari: salam pembuka, alasan, hari dan tanggal, waktu, tempat, acara.

c. Penutup/Kaki Surat, yang terdiri dari: nama badan usaha, jabatan, nama jelas, nomor induk pegawai, tembusan.

\section{Pembelajaran Kontekstual}

Pendekatan pengajaran dan pembelajaran kontekstual atau Contextual Teaching and Learning diperkenalkan dalam kegiatan penelitian ini. Perlunya pemakaian pendekatan ini didasarkan atas adanya kenyataan bahwa sebagian besar peserta didik belum mampu memanfaatkan ilmu yang mereka dipelajari di sekolah dalam kehidupan sehari-hari. Oleh sebab itu, melalui pendekatan ini diharapkan tujuan pembelajaran akan tercapai serta siswa dapat memaksimalkan keterampilan yang dimilikinya.

Johnson (Kunandar, 2007: 295) mengartikan pembelajaran kontekstual adalah suatu proses pendidikan yang bertujuan membantu siswa melihat makna dalam materi pelajaran yang mereka pelajari dengan cara menghubungkannya dengan konteks kehidupan mereka sehari-hari, yaitu dengan konteks lingkungan pribadi, sosial, dan budayanya. Selanjutnya, Hull's dan Sounders (Kokom Komalasari, 2013: 6) mengemukakan bahwa dalam pembelajaran kontekstual, siswa menemukan hubungan penuh makna antara ide-ide abstrak dengan penerapan praktis di dalam konteks dunia nyata. Siswa menginternalisasi konsep melalui penemuan, penguatan, dan keterkaitan.

Pembelajaran kontekstual memiliki karakteristik yang khas sehingga membedakannya dari pendekatan yang lain. Blanchad (Kokom Komalasari, 2013: 7) mengidentifikasikan tujuh karakteristik pendekatan kontekstual. Pertama, bersandar pada memori yang mengenai ruang. Kedua, mengintegrasikan beberapa subjek materi/ disiplin ilmu. Ketiga, nilai informasi didasarkan pada kebutuhan siswa. Keempat, menghubungkan informasi dengan dengan pengetahuan awal siswa. Kelima, penilaian autentik melalui aplikasi praktis atau pemecahan masalah nyata.

Johnson (Kokom Komalasari, 2013: 7) mengemukakan lima karakteristik pembelajaran kontekstual, yaitu sebagai berikut. Pertama, siswa membuat hubungan penuh makna. Kedua, siswa melakukan pekerjaan penting. Ketiga, siswa belajar mengatur sendiri. Ketiga, siswa bekerja sama dalam kelompok. Keempat, siswa berpikir kritis dan kreatif. Kelima, siswa memelihara keindividuannya. 
Berdasarkan uraian di atas dapat disimpulkan bahwa karakter pembelajaran kontekstual yaitu: (1) bersandar pada memori yang mengenai ruang; (2) Siswa membuat hubungan penuh makna; dan (3) Siswa berpikir kritis dan kreatif; (4) Siswa memelihara keindividuannya; dan (5) Siswa bekerja sama dalam kelompok.

Penelitian ini difokuskan pada empat karakter pembelajaran kontekstual. Pertama, bersandar pada memori yang mengenai ruang, yaitu siswa dibawa ke luar kelas. Kedua, Siswa belajar mengatur sendiri, yaitu siswa dibebaskan untuk memilih tempat pembelajaran di luar kelas sesuai dengan tema yang diinginkan oleh siswa. Ketiga, Siswa berpikir kritis dan kreatif, yaitu siswa bebas memilih tema dalam menulis puisi sehingga kreativitas siswa lebih terasah. Keempat, siswa memelihara keindividuannya.

Thonson (La Iru dan La Ode, 2012: 71) menjelaskan bahwa tujuan pembelajaran kontekstual yaitu menolong para siswa melihat makna yang ada di dalam materi akademik yang mereka pelajari. Ada delapan komponen untuk mencapai tujuan tersebut, yakni : (1) membuat keterkaitan-keterkaitan yang bermakna, (2) melakukan pekerjaan yang berarti, (3) melakukan pembelajaran yang diatur sendiri, (4) melakukan kerja sama, (5) berpikir kritis dan kreatif, (6) membantu individu untuk tumbuh dan berkembang, (7) mencapai standar yang tinggi, dan (8) menggunakan penilaian yang autentik.

Khilmiyah, dkk. (2005) menyatakan bahwa tujuan pembelajaran kontekstual adalah untuk membekali siswa berupa pengetahuan dan keterampilan yang lebih nyata karena inti dari pembelajaran kontekstual adalah untuk mendekatkan hal-hal yang lebih teoretis ke praktis, sehingga dalam pelaksaannya teori yang dipelajari diaplikasikan dalam dunia nyata. Sudarsono (2011) menyebutkan tujuh tujuan dalam pembelajaran kontektual. Tujuan tersebut sebagai berikut. Pertama, untuk memotifasi siswa dalam memahami makna materi yang dipelajari dengan mengkaitkan materi tersebut dengan konteks kehidupan sehari-hari siswa sehingga siswa memiliki pengetahuan dan keterampilan yang dapat diterapkan untuk menyelesaikan permasalahan-permasalahan sehari-hari. Kedua, supaya belajar itu tidak hanya sekedar menghafal tetapi perlu dengan adanya pemahaman. Ketiga, untuk mengembangkan minat pengalaman siswa. Keempat, melatih siswa berpikir kritis dan terampil dalam memproses pengetahuan sehingga dapat menemukan dan menciptakan hal yang bermanfaat bagi dirinya sendiri dan orang lain. Kelima, menciptakan pembelajaran yang lebih produktif dan bermakna. Keenam, mengajak anak pada suatu aktivitas yang mengkaitkan materi akademik dengan konteks kehidupan sehari-hari. Ketujuh, supaya siswa secara individu dapat menemukan dan mentransfer informasi-informasi kompleks dan juga siswa dapat menjadikan informasi tersebut untuk dirinya sendiri.

Berdasarkan uraian di atas dapat disimpulkan bahwa ada lima tujuan pembelajaran kontekstual. Pertama, membekali siswa berupa pengetahuan dan keterampilan yang lebih nyata. Kedua, memotivasi siswa untuk lebih memaknai materi pembelajaran dengan mengaitkan materi tersebut dengan pengalaman sehari-hari siswa. Ketiga, menciptakan pembelajaran yang lebih produktif dan bermakna. Keempat, siswa secara individu dapat menemukan dan mentransfer informasi-informasi kompleks dan juga siswa dapat 
menjadikan informasi tersebut untuk dirinya sendiri. Kelima, melatih siswa berpikir kritis dan terampil.

CTL sebagai suatu pendekatan pembelajaran memiliki asas-asas. Wina Sanjaya (2011: 264) menjelaskan bahwa CTL memiliki tujuh asas sebagai berikut.

\section{Konstruktivisme}

Konstruktivisme adalah proses membangun atau menyusun pengetahuan baru dalam stuktur kognitif siswa berdasarkan pengalaman pribadi atau pengetahuan yang sudah dimiliki siswa sebelumnya. Menurut kontruktivisme, pengetahuan itu terbentuk dari dua faktor, yaitu objek yang menjadi pengamatan dan kemampuan subjek untuk mengintrepetasikan objek tersebut.

2. Inkuiri

Inkuiri artinya proses pembelajarannya didasarkan pada pencarian dan penemuan melalui proses berpikir secara sistematis. Melalui proses itulah siswa diharapkan dapat berkembang secara utuh baik intelektual, mental, emosional, maupun pribadinya. Secara umum proses inkuiri dapat dilakukan melalui lima langkah, yaitu sebagai berikut. Pertama, merumuskan masalah. Kedua, mengajukan hipotesis. Ketiga, mengumpulkan data. Keempat, menguji hipotesis berdasarkan data yang ditemukan. Kelima, membuat kesimpulan.

\section{Bertanya (Questioning)}

Belajar pada hakikatnya adalah bertanya dan menjawab pertanyaan. Bertanya merupakan refleksi dari keingintahuan siswa. Dalam proses pembelajaran CTL, guru tidak menyampaikan informasi begitu saja, akan tetapi memancing agar siswa dapat menemukannya sendiri. Peran bertanya merupakan hal penting, sebab melalui pertanyaan-pertanyaan guru dapat membimbing dan mengarahkan siswa untuk menemukan setiap materi yang dipelajarinya.

4. Masyarakat belajar (Learning Community)

Penerapan masyarakat belajar dalam CTL dapat dilakukan dengan menerapkan pembelajaran melalui kelompok belajar. Siswa dibagi dalam kelompok-kelompok yang anggota bersifat heterogen.

5. Pemodelan (Modeling)

Asas pemodelan adalah proses pembelajaran dengan memperagakan sesuatu sebagai contoh yang dapat ditiru oleh setiap siswa. Proses pemodelan tidak terbatas dari guru saja, tetapi juga guru dapat memanfaatkan siswa yang dianggap memiliki kemampuan. Modeling merupakan asas yang cukup penting dalam pembelajaran CTL, karena melalui modeling siswa dapat terhindar dari pembelajaran yang teoretis-abstrak yang memungkinkan terjadinya verbalisme.

6. Refleksi (Reflection)

Refleksi adalah proses pengendapan pengalaman yang telah dipelajari dan dilakukan dengan cara mengurutkan kembali kejadian-kejadian atau peristiwa pembelajaran yang telah dilaluinya. Setiap akhir proses pembelajaran CTL, guru selalu memberikan kesempatan untuk merenung atau mengingat kembali apa saja yang telah dipelajarinya. Siswa dibiarkan menafsirkan secara bebas pengalamannya sendiri, sehingga siswa dapat menyimpulkan tentang pengalaman belajarnya. 


\section{Penilaian Nyata (Authentic Assessment)}

Keberhasilan pembelajaran dalam CTL ditentukan oleh perkembangan semua aspek yang dimiliki oleh siswa. Penilaian keberhasilan didapat dari hasil tes dan proses belajar melalui penilaian nyata. Penilaian nyata adalah proses yang dilakukan guru untuk mengumpulkan informasi tentang perkembangan belajar yang dilakukan siswa. Penilaian ini dilakukan secara terintegrasi dengan proses pembelajaran dan secara terus menerus selama kegiatan pembelajaran berlangsung.

Kokom Komalasari (2013: 38) menjelaskan bahwa materi pembelajaran yang dikembangkan berdasarkan pendekatan kontektual memiliki karakteristik tersendiri, yaitu sebagai berikut. a) Keterkaitan dengan konteks lingkungan tempat siswa berada yang meliputi: (1) lingkungan fisik, (2) lingkungan sosial, (3) lingkungan budaya, (4) lingkungan politis, (5) lingkungan psikologis, dan (6) lingkungan ekonomis. b) Keterkaitan dengan materi pelajaran lain secara terpadu. c) Mampu diaplikasikan dalam kehidupan siswa. d) Memberikan pengalaman langsung melalui kegiatan inkuiri. e) Mengembangkan kemampuan kooperatif sekaligus kemandirian. f) Mengembangkan kemampuan melakukan refleksi.

Penelitian ini difokuskan pada empat materi pembelajaran yang berbasis kontekstual. Pertama, keterkaitan dengan konteks lingkungan dimana siswa berada yang meliputi lingkungan fisik. Kedua, mampu diaplikasikan dalam kehidupan seharihari. Ketiga, memberikan pengalaman langsung. Keempat, mengembangkan kemampuan refleksi, kemampuan refleksi tersebut diterapkan pada setiap akhir pembelajaran yaitu siswa merefleksi kembali materi yang sudah dipelajari.

Setiap pembelajaran pasti memiliki kelebihan, termasuk pembelajaran kontekstual. Wina Sanjaya (2011: 253) memaparkan bahwa pembelajaran kontekstual menjadi lebih bermakna dan riil, lebih produktif dan mampu menumbuhkan penguatan konsep kepada siswa, kelas dalam pembelajaran kontekstual bukan sebagai tempat untuk memperoleh informasi, akan tetapi sebagai tempat untuk menguji data hasil temuan mereka di lapangan, materi pembelajaran dapat menciptakan suasana pembelajaran yang bermakna, dan penerapan pembelajaran kontekstual dapat menciptakan suasana pembelajaran yang bermakna.

Ditjen Dikdasmen (Kokom Komalasari, 2013: 18) menyatakan ada tujuh kelebihan pembelajaran kontekstual, diantaranya sebagai berikut. Pertama, siswa secara aktif terlibat dalam proses pembelajaran. Kedua, pembelajaran dikaitkan dengan kehidupan nyata dan atau masalah yang disimulasikan. Ketiga, keterampilan dikembangkan atas dasar pemahaman. Keempat, siswa belajar dari teman melalui kerja kelompok, diskusi, dan saling mengoreksi. Kelima, bahasa yang diajarkan dengan bahasa yang komunikatif. Keenam, siswa diminta bertanggungjawab memonitoring dan mengembangkan pembelajaran mereka masing-masing. Ketujuh, hasil belajar diukur dengan berbagai cara: proses bekerja, hasil karya, penampilan, rekaman, tes, dll. Sumber lain, red kopite geography (2013), menyebutkan ada dua kelebihan pembelajaran kontekstual, yaitu sebagai berikut.

a. Pembelajaran menjadi lebih bermakna dan riil karena dalam pembelajaran kontekstual siswa dituntut untuk dapat menangkap hubungan antara pengalaman belajar di sekolah 
dengan kehidupan nyata.

b. Pembelajaran lebih produktif dan mampu menumbuhkan penguatan konsep kepada siswa karena model ini menganut aliran kontruktivisme, dimana siswa dituntun untuk menemukan pengetahuannya sendiri.

Berdasarkan beberapa uraian di atas dapat disimpulkan bahwa kelebihan dari pembelajaran kontekstual ada enam. Pertama, lebih bermakna dan riil, lebih produktif dan mampu menumbuhkan penguatan konsep kepada siswa. Kedua, siswa secara aktif terlibat dalam proses pembelajaran. Ketiga, pembelajaran dikaitkan dengan kehidupan nyata dan atau masalah yang disimulasikan. Keempat, keterampilan dikembangkan atas dasar pemahaman. Kelima, siswa belajar dari teman melalui kerja kelompok, diskusi, dan saling mengoreksi. Keenam, hasil belajar diukur dengan berbagai cara: proses bekerja, hasil karya, penampilan, rekaman, tes.

\section{METODE}

Metode penelitian menggunakan penelitian tindakan kelas (PTK) yang dilaksanakan dalam dua siklus setiap siklus terdiri dua kali pertemuan, dengan empat tahap penelitian: perencanaan, pelaksanaan, pengamatan dan refleksi. Subjek penelitian ini adalah siswasiswi kelas 8 G SMP Negeri 6 Sukoharjo tahun ajaran 2017/2018. Dengan jumlah 20 siswa. Teknik pengumpulan data yang digunakan adalah observasi, wawancara, tes, dan dokumentasi. Analisis data yang digunakan dalam penelitian ini adalah analisis deskriptif kualitatif.

\section{PEMBAHASAN}

Setelah peneliti melaksanakan tindakan penelitian melalui penerapan pendekatan kontekstual, secara empiris diperoleh data peningkatan prestasi belajar bahasa Inggris materi mendiskripsikan teks sederhana bentuk undangan dan bagian-bagiannya siswa kelas 8 G SMP Negeri 6 Sukoharjo Kecamatan Sukoharjo, Kabupaten Sukoharjo Semester I Tahun Pelajaran 2017/2018 dari kondisi awal, siklus I dan siklus II sebagai berikut.

Tabel 1. Peningkatan Prestasi Belajar Siswa

\begin{tabular}{|c|c|c|c|}
\hline Uraian & Kondisi awal & Siklus I & Siklus II \\
\hline Tindakan & Belum menerapkan & Sudah menerapkan & Sudah menerapkan \\
Pembelajaran & metode kontekstual & metode kontekstual & metode kontekstual \\
\hline Nilai terendah & 55 & 60 & 70 \\
Nilai tertinggi & 75 & 90 & 90 \\
Nilai rata-rata & 70 & 75 & 85 \\
KKM & 75 & 75 & 75 \\
Ketuntasan & 11 siswa (55\%) & 14 siswa (70\%) & 17 siswa (85\%) \\
\hline
\end{tabular}

Melalui penerapan pendekatan kontekstual dapat meningkatkan prestasi belajar bahasa Inggris materi mendiskripsikan teks sederhana bentuk undangan dan bagian-bagiannya.

Pada kondisi awal peneliti belum menerapkan pendekatan kontekstual. Nilai rata-rata siswa kelas $8 \mathrm{G}$ adalah 70, masih di bawah nilai KKM yang ditetapkan yaitu 75 . Nilai 
tertinggi siswa 75, nilai terendah 55 dan jumlah siswa kelas $8 \mathrm{G}$ yang mencapai nilai KKM hanya 11 siswa (55\%) dari total 20 siswa kelas 8 G SMP Negeri 6 Sukoharjo.

Pada siklus I guru peneliti sudah menerapkan pendekatan kontekstual dalam pembelajaran bahasa Inggris materi mendiskripsikan teks sederhana bentuk undangan dan bagian-bagiannya. Nilai rata-rata prestasi belajar bahasa Inggris materi mendiskripsikan teks sederhana bentuk undangan dan bagian-bagiannya siswa kelas 8 G SMP Negeri 6 Sukoharjo adalah 75, nilai tertinggi 90 dan nilai terendah adalah 60. Sedangkan jumlah siswa yang mencapai nilai KKM sebanyak 14 siswa (70\%) dari total 20 siswa kelas $8 \mathrm{G}$ SMP Negeri 6 Sukoharjo.

Pada siklus II, nilai rata-rata prestasi belajar bahasa Inggris materi mendiskripsikan teks sederhana bentuk undangan dan bagian-bagiannya siswa kelas 8 G SMP Negeri 6 Sukoharjo adalah 85, nilai tertinggi 90 dan nilai terendah 70. Jumlah siswa yang mencapai nilai KKM sebanyak 17 siswa (85\%) dari total 20 siswa kelas 8 G SMP Negeri 6 Sukoharjo.

Jadi, melalui penerapan pendekatan kontekstual dapat meningkatkan prestasi belajar bahasa Inggris materi mendiskripsikan teks sederhana bentuk undangan dan bagianbagiannya dari kondisi awal nilai rata-rata 70 dengan ketuntasan 55\% ke kondisi akhir pada siklus II nilai rata-rata 85 dengan ketuntasan $85 \%$ pada siswa kelas 8 G SMP Negeri 6 Sukoharjo semester I Tahun Pelajaran 2017/2018.

Hasil tindakan secara empirik yaitu: melalui penerapan pendekatan kontekstual dapat meningkatkan prestasi belajar bahasa Inggris materi mendiskripsikan teks sederhana bentuk undangan dan bagian-bagiannya dari kondisi awal nilai rata-rata 70 dengan ketuntasan 55\% ke kondisi akhir pada siklus II nilai rata-rata 85 dengan ketuntasan $85 \%$ pada siswa kelas 8 G SMP Negeri 6 Sukoharjo semester I Tahun Pelajaran 2017/2018.

\section{SIMPULAN}

Hipotesis menyatakan diduga melalui penerapan pendekatan kontekstual (Contextual Teaching and Learning) dapat meningkatkan prestasi belajar bahasa Inggris materi mendiskripsikan teks sederhana bentuk undangan dan bagian-bagiannya pada siswa kelas 8 G SMP Negeri 6 Sukoharjo Semester I Tahun Pelajaran 2017/2018.

Dari data empirik menyatakan melalui penerapan pendekatan kontekstual dapat meningkatkan prestasi belajar bahasa Inggris materi mendiskripsikan teks sederhana bentuk undangan dan bagian-bagiannya dari kondisi awal nilai rata-rata 70 dengan ketuntasan 55\% ke kondisi akhir pada siklus II nilai rata-rata 85 dengan ketuntasan $85 \%$ pada siswa kelas 8 G SMP Negeri 6 Sukoharjo Semester I Tahun Pelajaran 2017/2018.

Sehingga dapat disimpulkan bahwa melalui penerapan pendekatan kontekstual dapat meningkatkan prestasi belajar bahasa Inggris materi mendiskripsikan teks sederhana bentuk undangan dan bagian-bagiannya pada siswa kelas 8 G SMP Negeri 6 Sukoharjo semester I Tahun Pelajaran 2017/2018. 
Erna Rumiyatun/ Edunomika Vol. 02 No. 01 (Pebruari 2018)

\section{DAFTAR PUSTAKA}

Ahmadi. (1998). Faktor-Faktor Yang Mempengaruhi Belajar. Jakarta: PT Raja Grafindo Persada.

A. Sardiman. (2012). Interaksi dan Motivasi Belajar Mengajar. Jakarta: PT Rajagrafindo Persada.

Burhan Nurgiyantoro. (2012). Penilaian Pembelajaran Bahasa Berbasis Kompetensi. Yogyakarta: BPFE-Yogyakarta.

Ditjen Dikdasmen, Depdiknas RI. (2003). Pendekatan Kontekstuan/Contextual Teaching and Learning (CTL), Jakarta: Ditjen Dikdasmen, Depdiknas RI.

Dimyati dan Mudjiono. 2002. Belajar dan Pembelajaran. Jakarta: Penerbit Rineka Cipta

Keraf. G. (1995). Eksposisi. Jakarta" Grasindo.

Kilmiah. Dkk. (2005). Metode Pengajaran Pendidikan Kewarganegaraan. Yogyakarta: PP Muhammadiyah.

Kokom Komalasari. (2013). Pembelajaran Kontekstual Konsep dan Aplikasi. Bandung: PT Refika Aditama.

Kunandar. (2007). Guru Profesional Implementasi Kurikulum Tingkat Satuan Pendidikan (KTSP) dan Sukses Sertifikasi Guru. Jakarta: Rajagrafindo Persada

La Iru, \& La Ode Safiun Arihi. (2012). Analisis Penerapan Pendekatan, Metode, Strategi, dan Model-Model Pembelajaran. Yogyakarta: Multi Presindo.

M. Sobri Sutikno. (2010). Strategi Belajar Mengajar Melalui Penanaman Konsep Umum dan Konsep Islami. Bandung: Refika Aditama.

Muhibudin Syah (1998). Psikologi Pendidikan Dengan Pendekatan Baru. Bandung: Remaja Rosdakarya.

Nasution S. 1990. Pengertian Belajar. Bandung : Bumi Aksara

Poerwanto, Ngalim. 1986. Prinsip-prinsip dan Tehnik Evaluasi Pengajaran. Bandung: Remaja Karya

Slameto. (2000). Belajar dan Faktor-faktor Yang mempengaruhinya. Jakarta: Rineka Cipta.

Tarigan, H.G. 1995. Menulis: Suatu Keterampilan Berbahasa. Bandung: Angkasa. 
Erna Rumiyatun/ Edunomika Vol. 02 No. 01 (Pebruari 2018)

Tho'in, M. (2017). Pembiayaan Pendidikan Melalui Sektor Zakat. Al-Amwal: Jurnal Ekonomi dan Perbankan Syari'ah, 9(2).

Wina Sanjaya. (2011). Strategi Pembelajaran Berorientasi Standar Proses Pendidikan. Jakarta: Prenada Media.

Winkel, W.S. 1996. Psikologi Pengajaran. Jakarta: Grasindo. 